\title{
The occurrence of microplastics in freshwater systems - preliminary results from Krakow (Poland)
}

\author{
Marzena Połeć, Urszula Aleksander-Kwaterczak, Katarzyna Wątor, Ewa Kmiecik \\ AGH University of Science and Technology, Faculty of Geology, Geophysics and Environmental Protection; \\ al. A. Mickiewicza 30,30-059 Krakow, Poland, e-mail: polec@agh.edu.pl
}

(C) 2018 Authors. This is an open access publication, which can be used, distributed and reproduced in any medium according to the Creative Commons CC-BY 4.0 License requiring that the original work has been properly cited.

Received: 31 July 2018; accepted: 11 November 2018; first published online: 20 November 2018

\begin{abstract}
The results of research conducted in recent years indicates that microplastic particles are widely distributed in the aquatic environment. The investigations are mostly focused on marine waters and there is still a lack of information about their presence in both surface water and groundwater. In this paper, preliminary results of research conducted in Poland are presented. Different types of water samples were collected. Five litres of each sample were filtered through $0.4 \mu \mathrm{m}$ glass fibre filters. In the first stage, visual identification was conducted using a stereomicroscope. Additionally, some interesting fragments were examined by means of SEM/EDS method. In the case of rivers water samples, which were characterized by a high content of organic matter and minerals, the visibility of microplastics could be reduced. In the sample from the Vistula River, some particles similar to microplastics were found. In the groundwater samples, some blue and green particles which supposed to be plastic were found by the stereomicroscope. Additional analysis with the DXR Raman Microscope method gave no clear results. The samples were too small and the plastic particles were very dispersed which prevented correct analysis. SEM analysis showed irregularly shaped particles which were considered to be microplastics. Considering the chemical composition, carbon predominated.
\end{abstract}

Keywords: surface water, groundwater, plastic particles, Poland

\section{INTRODUCTION}

The amount of plastic production increases from year to year with a small degree of recycling. Many people are not aware of the danger connected with this fact because they have been taught that plastic is a safe material. The problem with plastic is serious because its removal from the environment is difficult. The degradation time of PET bottles ranges from 450 to 1000 years. This means that the first produced bottle still exists, and will even "outlive" us by several hundred years. This highlights the scale of the problem. About 335 million tons of plastics are produced annually in the world. This number is constantly increasing with very little neutralization of plastic waste, the level of which has reached about 25\% in recent years in Poland (Andrady 2011, Bogusz \& Cejner 2015, Fleituch 2016, Plastics 2017: 16, 22, 33, Pagter et al. 2018). Despite a significant improvement in the quality of tap water, consumption of bottled waters is constantly growing, and as a result, the number of plastic waste is increasing (Kłos 2016). It causes littering of the natural environment.

Microplastic is a novel problem which is not yet fully understood and requires a lot of investigation in terms of sampling methods, analysis, migration pathways or factors which impact on the plastic particles (Hidalgo-Ruz et al. 2012, Dris et al. 2015b, Fleituch 2016). Despite the lack of an official document confirming the definition of a microplastic, different concepts function in the 
scientific community. A relatively new conception, it was used for the first time in 2004 for plastic particles with a diameter of about $20 \mu \mathrm{m}$, which were discovered in seawater samples (Thompson et al. 2004). Nowadays, this term is used for particles with a diameter of less than $5 \mathrm{~mm}$. Small plastic particles were observed already in 1972 in the Sargasso Sea. An average plastic content at sea level reached 3500 pieces $/ \mathrm{km}^{2}$ (Carpenter et al. 1972). Plastic particles have also been discovered in other parts of the world, such as the north-western part of the Atlantic (Colton et al. 1974).

Despite the fact that the upper limit of size is considered as $5 \mathrm{~mm}$ in a large number of publications (e.g. Faure et al. 2012, Free et al. 2014, Wagner et al. 2014, Davis \& Murphy 2015, Dris et al. 2015a, 2015b, Graca et al. 2017, Manalu et al. 2017, Mrowiec 2017, Dris et al. 2018, Gasperi et al. 2018, Li et al. 2018, Sighicelli et al. 2018, Westphalen \& Abdelrasoul 2018), some scientists also distinguish a division into macroplastics, i.e. particles larger than $5 \mathrm{~mm}$ (Faure et al. 2012). Whereas Andrady (2011) considers that microplastics undergo continuous disintegration processes, which indicates that there is a possibility of nanoparticles in the aqueous environment.

Many researchers are focused on the effects of contamination which can be visible in the marine environment. However, it is important to pay more attention to sources which are primarily located in urban areas. From such places, microplastics are transported by surface waters to the seas and oceans (Lechner et al. 2014, Dris et al. 2015b, Hurley at al. 2018, Wagner \& Lambert 2018).

Microplastics present in the aquatic environment reach it mainly from the land. They can be in the form of waste, which will become fragmented due to UV radiation, mechanical abrasion and biological degradation (Dris et al. 2015b) or come from wastewater treatment plants (Mrowiec 2018) and are in the form of microbeads from cleansing gels or fibres from washing synthetic clothes (Lončarski et al. 2018). It has been shown that washing machines can generate over 1,900 plastic fibres in the single cycle (Browne et al. 2011). The amount of microfibres will continue to increase in the future, and the only way to stop this is to avoid or improve the biodegradability of polymers used in textiles (Carr 2017). The appearance of microplastics in sewage sludge, on the one hand, is being reduced because of the effective treatment of sewage and concomitant reduction in the amount found in environments, yet remains a further threat because sewage sludge is commonly used for agricultural fertilization (Dris et al. 2015b, Westphalen \& Abdelrasoul 2018).

Plastics are lightweight materials that can be moved by wind, rain, water flow but also by living organisms. Wind can transport microplastics from the land, e.g. from landfills or as a result of burning garbage, and then through rain or animal activities. Airborne fibres and microparticles come from synthetic clothing, degradation of microfine, garbage dumps and incineration of rubbish. They fall together with rain, augmenting rivers, lakes, as well as seas and oceans. This suggests the possibility of microplastics reaching groundwater, even more realistic if we take into account the studies on the migration of microplastics in the soil through the activity of earthworms (Rillig et al. 2017). After entering freshwater or the marine environment, they may pose a potential threat to health and life of humans and animals but the impact of microplastics on health is not fully explored (Mato et al. 2001, Rios et al. 2007, Fleituch 2016).

During transport, plastic particles undergo a series of erosion processes which result in increasingly fragmented material. They include mechanical erosion, disintegration under the influence of UV radiation, as well as mechanical abrasion and biological degradation in the case of biodegradable plastics (Dris et al. 2015b).

Although plastics are considered chemically inert, many scientists pay attention to the absorption of harmful and toxic compounds which are transported by plastic particles (Graham \& Thompson 2009, Ashton et al. 2010, Hidalgo-Ruz et al. 2012).

Experiences of researchers from Europe and all over the world suggest that microplastics should also be expected in inland waters. However, it is futile to look for freshwater research in Poland. There are only a few publications about microplastics and research refers to the problem of microplastics in the marine environment. The authors focus especially on its presence in seawater, bottom and coast sediments (Graca et al. 2017), and the threat it poses for marine fauna, due to the sorption of pollution on its surface (Jastrzębska \& Jurczak 2012, Bogusz \& Cejner 2015, Bogusz \& Oleszczuk 2016, Fleituch 2016, Heimowska 2016, Mrowiec 2017). During the 
research cruise, AREX 2017 Dąbrowska from the University of Warsaw conducted pilot studies on the presence of microplastics in the arctic marine environment (Sprawozdanie). Another research project has been conducted on the content of microplastics in otter excrement. Even though the studies showed small amounts of microplastics, they nevertheless indicate its presence in the freshwater environment (Butrykowska 2017). Any research conducted in the freshwater environment in Poland will therefore be innovative and allow for the recognition of the presence of microplastics in various types of water. This will allow the problem to be indicated and demonstrate the need for further research.

\section{PRELIMINARY RESEARCH}

\section{Material and methods}

Different kinds of water samples were taken in March 2018 (Tab. 1) to check for the presence of microplastics. Two samples were collected from Polish rivers (the Vistula and Rudawa in the Krakow region), as well as another two from a groundwater intake (Zabierzów village, near Krakow). An additional sample was specially prepared as an enriched sample where some particles of microplastic were intentionally added to the water. This sample was prepared on the basis of tap water in which laundry had been done with the addition of some cosmetic pellets (rinsed from the cleansing gel) and pieces scraped from a plastic pot and bottles. Because of a lack of a standard protocol for sample collection for microplastic analysis in water samples, and the preliminary character of the research, we decided to take samples directly from the water reservoirs examined. Brand new polypropylene bottles, previously rinsed three times with distilled water, were used (Carretero et al. 2017). The exception was the second sample of groundwater, where glass bottles calcined in the laboratory were used. The presence of microplastics in the groundwater stored in plastic and the lack of such particles in the sample from a glass vessel may indicate the migration of substances analysed from polypropylene bottles material. For the collection of samples from the Vistula and Rudawa rivers, five litre vessels were immersed directly next to the water surface. Samples were taken in places where water had a difficult outflow (local small bays) and greater accumulations of pollutants were expected. The groundwater samples come from a deep well (raw Quaternary groundwater from a small well where no treatment is used) and pass through the home plastic installation. They were taken after a whole night of stagnation without prior water rinsing. To reduce the possibility of polypropylene degradation and the migration of microplastic particles from the bottle walls into water, all samples were protected against contact with sunlight and UV radiation during storage. What is more, all samples were immediately transported to the laboratory where the volume of 5 litres of each sample was vacuum filtered by a Sartorius filtration apparatus (type 16510, PC) through glass fibre filters (GF-5, MACHEREY-NAGEL) with a pore $0.4 \mu \mathrm{m}$. The visual assessment of the precipitates on the dried filters was conducted using a stereomicroscope (Nikon eclipse LV100POL). Selected fragments, where particles resembling microplastics were identified, were additionally examined by means of the SEM (FEI Quanta 200 FEG) with an X-ray microanalysis device (EDS) and DXR Raman Microscope (Thermo Scientific) methods.

Table 1

Samples of water collected for analyses

\begin{tabular}{|c|c|c|c|c|}
\hline $\begin{array}{l}\text { Sample } \\
\text { number }\end{array}$ & Component & Description & Container & Aim of sample collection \\
\hline 1 & \multirow{2}{*}{ surface water } & Vistula River (Krakow) & plastic & \multirow{2}{*}{$\begin{array}{l}\text { occurrence of microplastic in Polish } \\
\text { rivers }\end{array}$} \\
\hline 2 & & Rudawa River (Krakow) & plastic & \\
\hline 3 & \multirow{2}{*}{ groundwater } & \multirow{2}{*}{$\begin{array}{l}\text { groundwater (potable water, } \\
\text { untreated as a source from } \\
\text { Zabierzów village) }\end{array}$} & glass & $\begin{array}{l}\text { occurrence of microplastic in water } \\
\text { coming from untreated groundwater }\end{array}$ \\
\hline 4 & & & plastic & $\begin{array}{l}\text { migration/degradation of microplastic } \\
\text { from the vessel used }\end{array}$ \\
\hline 5 & enriched tap water & $\begin{array}{l}\text { water after washing clothes and } \\
\text { cosmetic pellets (tap water from } \\
\text { the Krakow municipal supply) }\end{array}$ & plastic & $\begin{array}{l}\text { check the possibility of microplastic } \\
\text { recognizing with the methods used }\end{array}$ \\
\hline
\end{tabular}




\section{Results (Figs. 1-6)}

Particles of microplastic were not detected in the sample collected from the Rudawa River. In the sample from the Vistula River, a particle was found resembling a cosmetic pellet (Fig. 1). However, the analysis of the chemical composition showed the dominating contribution of silicon and oxygen from which the fibre filter used was built, as well as Fe. Therefore, it does not resemble the composition of plastics. This may be due to the influence of the sample matrix and the small size of the particle considered to be microbeads. In groundwater samples, some blue and green particles which were supposed to be plastic debris were found by the stereomicroscope (Fig. 2).
Their shapes and colours suggest anthropogenic origin but additional analysis with the DXR Raman Microscope method gave no certain results. Figures 3 and 4 show irregularly shaped particles found in groundwater samples that were considered to be microplastics. In the chemical composition, carbon, which is also a component of polymers that make up plastics, appeared. Because of the small and thin size of the particle examined, a high content of $\mathrm{Si}$ and $\mathrm{O}$ resulting from the fibre filter material was also observed. During the experiment, it was impossible to identify clearly if microplastic particles found in the groundwater collected in a plastic container differed from those observed in the sample stored in a glass vessel.
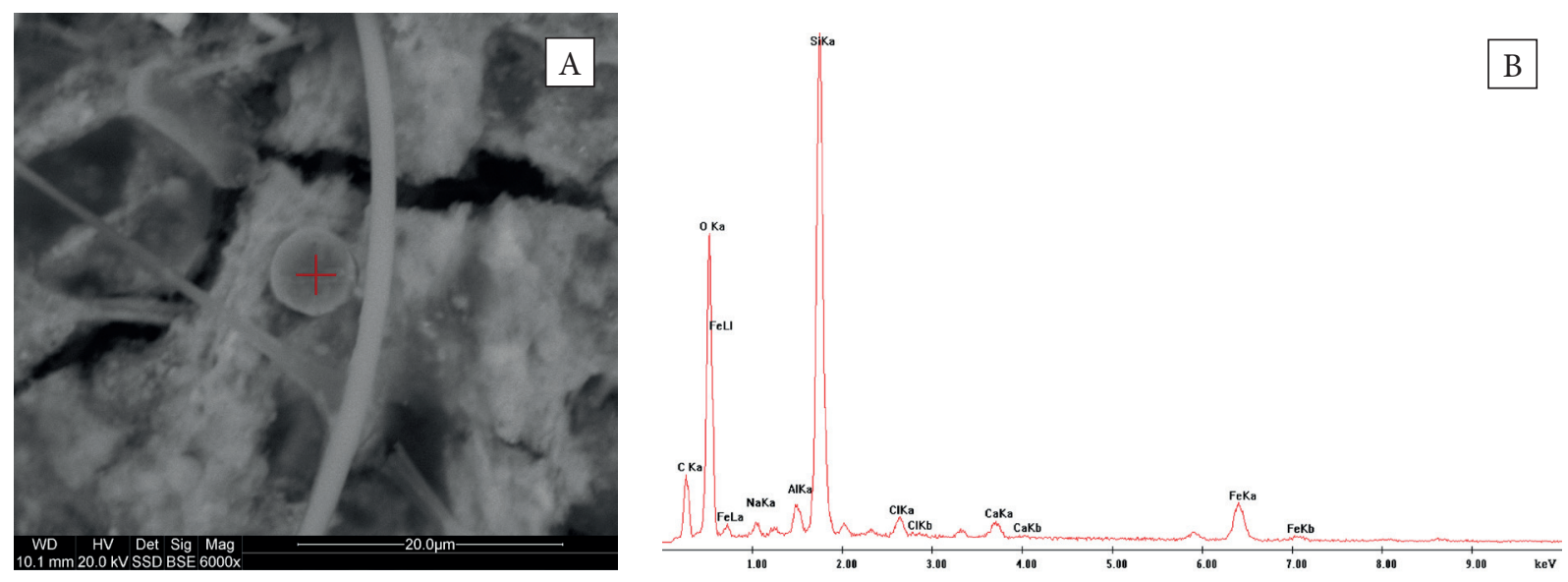

Fig. 1. Microbead in the Vistula River sample: A) picture from SEM; red cross marks location of EDS point analysis; B) analysis of the chemical composition by EDS

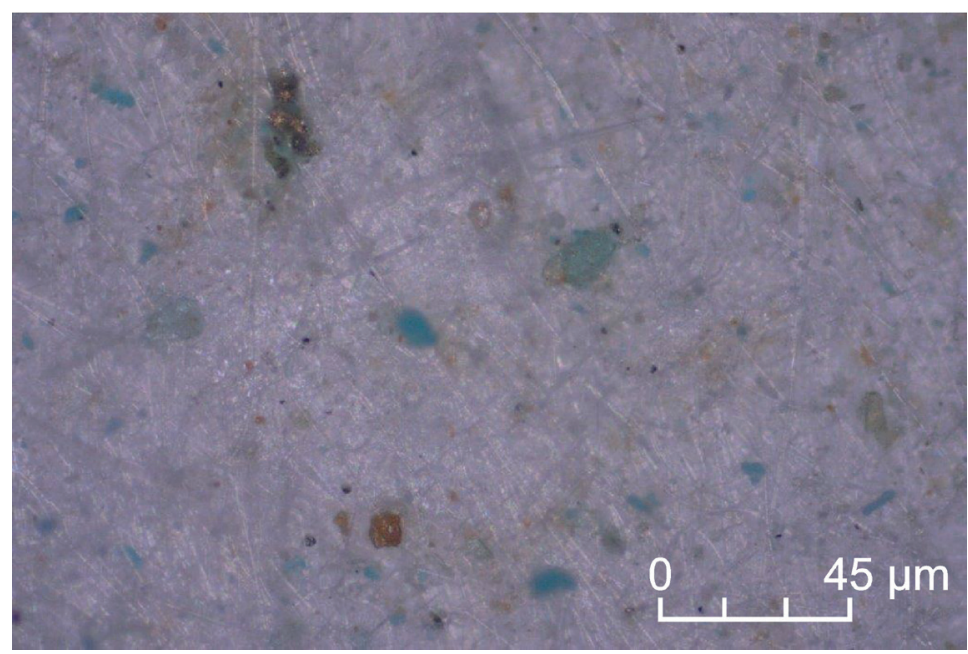

Fig. 2. Blue and green particles of microplastic in groundwater collected in the glass vessel (stereomicroscope image) 

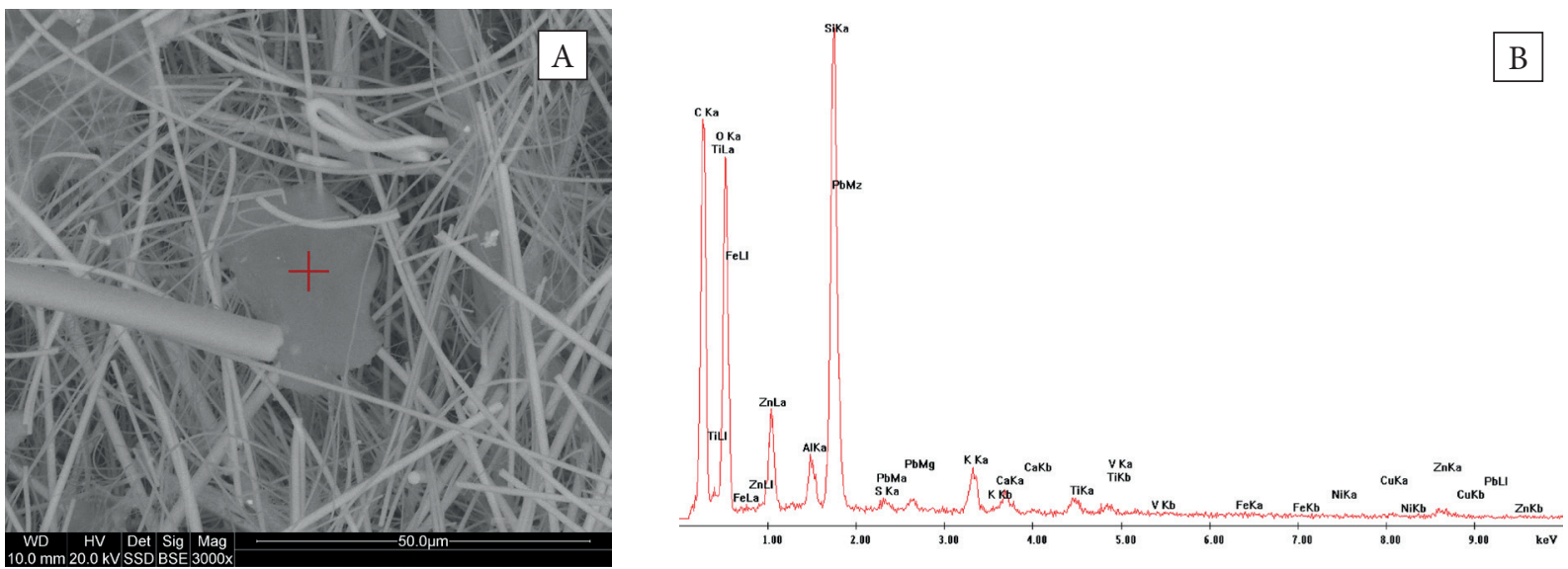

Fig. 3. Found particle in the groundwater sample collected in the plastic bottle: A) picture from SEM; B) analysis of the chemical composition by EDS
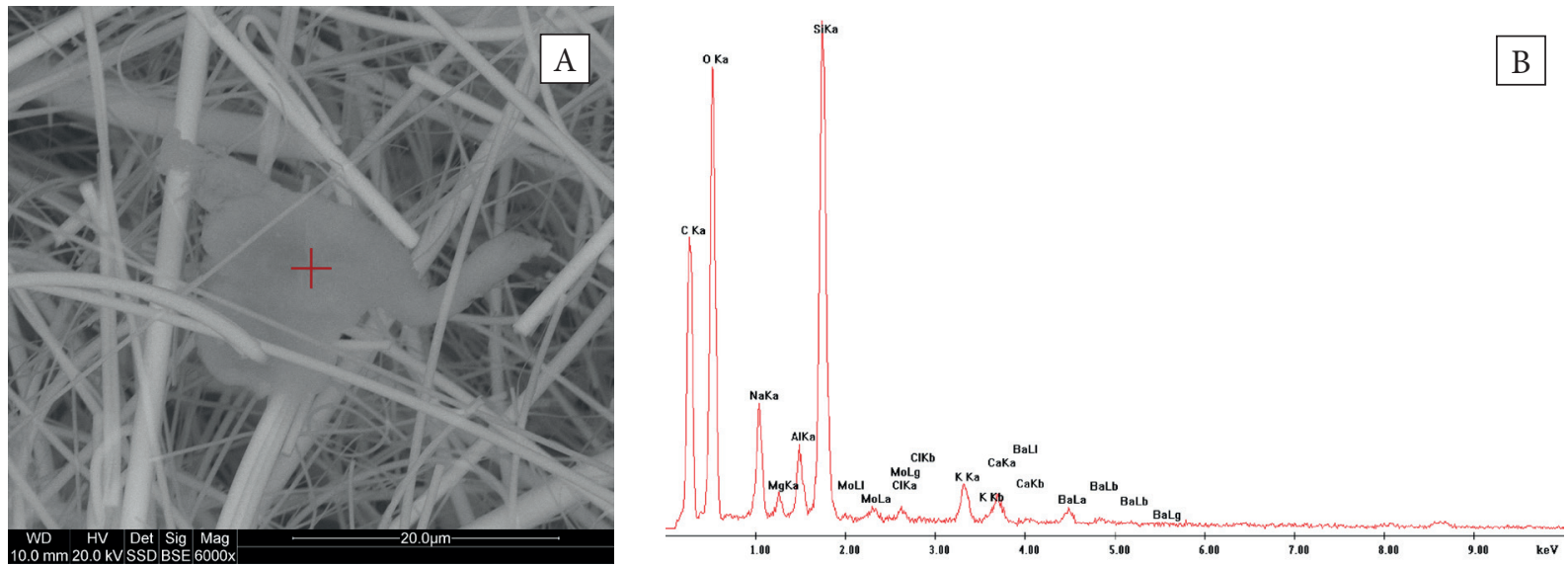

Fig. 4. Found particle in the groundwater sample collected in the plastic bottle: A) picture from SEM; B) analysis of the chemical composition by EDS
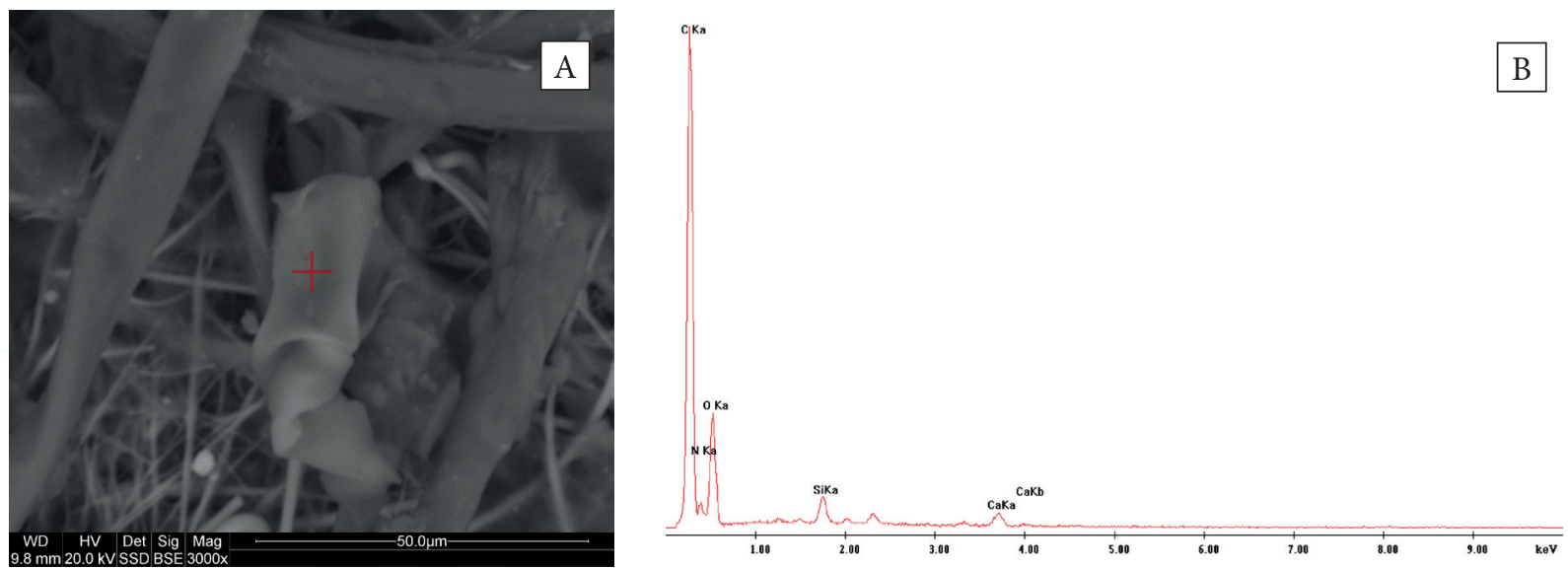

Fig. 5. The scraped piece from a plastic pot that has been intentionally added to the enriched sample: A) picture from SEM; B) analysis of the chemical composition by EDS 


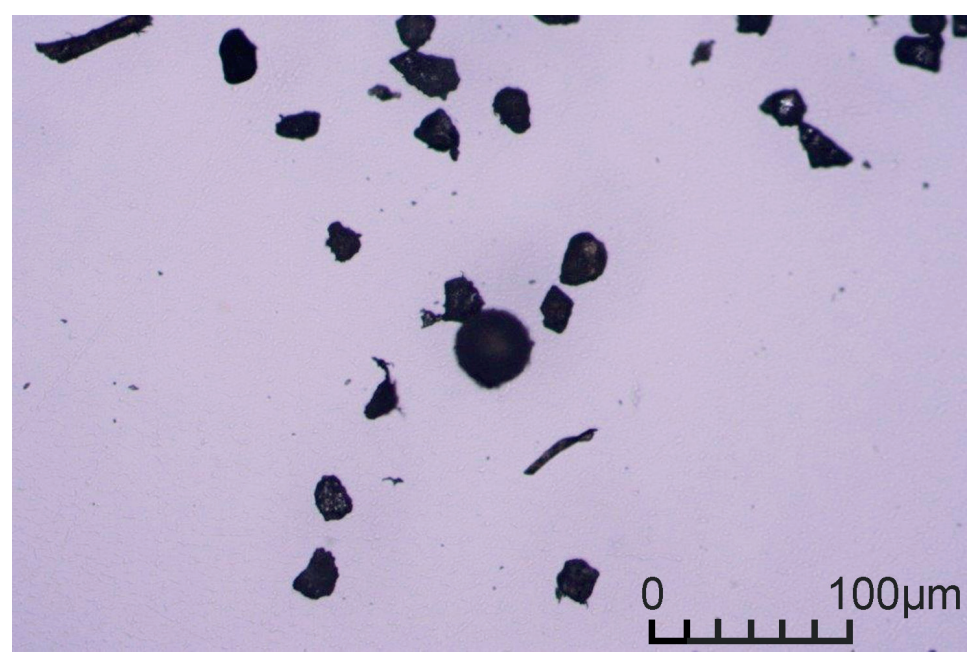

Fig. 6. Plastic pellet in the enriched sample (stereomicroscope image)

However, the lack of microplastic particles in water from the Rudawa River suggests that the process of microplastic leaching is not observed in the short period of water samples storage. In the enriched sample, different particles considered as plastics were found. Figure 5 shows a scraped piece from a plastic pot that had been intentionally added to the enriched sample. Chemical composition conducted with Energy Dispersive X-Ray Spectroscopy showed that carbon is the main building element. Some cosmetic pellets (in the shapes of a circle and rhomboid) were also found using the stereomicroscope (Fig. 6).

\section{DISCUSSION}

In the Vistula River sample, a particle was found which was considered to be a cosmetic pellet (Fig. 1). Additional analysis of chemical composition with EDS showed a high presence of silicon, oxygen and iron which does not confirm our assumptions about plastic origin. The sample matrix and the small particle size probably had a large impact on the results.

In the water sample from the Rudawa River, the presence of microplastics was not detected. This may be due to the fact that too small a volume of water was taken for research. However, some floating plastic bottles were observed on the surface of water. This indicates that microplastics can sooner or later appear in this river channel and further investigation is needed. Additionally, samples taken from rivers were characterized by a high content of organic matter and minerals, which could reduce the visibility of microplastic particles. For such samples, the matrix should be eliminated or even reduced i.e. by oxidation of organic compounds with $30 \%$ hydrogen peroxide (Sighicelli et al. 2018), 70\% ethanol (Free et al. 2014), 95\% ethanol (Eriksen et al. 2018), 100\% ethanol (Barnes et al. 2010) or with 70\% isopropyl alcohol (Eriksen et al. 2013, 2018).

It is also possible that there was a high-density plastic which (as in the case of mineral elements) falls more easily to the bottom zone (Eisma \& Cadeé 1991, Morét-Ferguson et al. 2010). The river environment is very dynamic and a lot of the physical factors can influence the transport of solid elements in freshwater. These are primarily water depth, flows velocity, bottom topography (Simpson et al. 2005), storms, floods and anthropogenic activity (Moatar et al. 2006). Therefore, it is advisable to carry out further research which will involve the collection and analysis of water samples in different sections of the river and in various seasons to present knowledge of the spatial and temporal distribution of plastic particles.

There is still a large problem with the reliable detection of microplastics, including the ability to capture plastic particles from water, their separation from other particles and, finally, identifying 
the types of plastics (Eriksen et al. 2013, Eerkes-Medrano et al. 2015).

The sampling method can have a strong influence on the results, particularly concerning the smallest particles of plastic (Song et al. 2014). Many researchers implemented a manta trawl to collect samples from lakes and rivers. It is originally used to take microplastics from the surface of seas and oceans. The manta trawl is generally attached to a boat and is a construction with a width of approximately $60 \mathrm{~cm}$ and a height of approximately $20 \mathrm{~cm}$, with wings holding it on the water. Behind the hole, there is an attached a plankton or neuston net with a mesh diameter of usually $300-335 \mu \mathrm{m}$. The structure is placed on the surface of water in such way that the upper water layer gets to the net (Moore et al. 2011, Faure et al. 2012, Eriksen et al. 2013, Free et al. 2014, Davis \& Murphy 2015, Dris et al. 2015b, Eriksen et al. 2018, Li et al. 2018, Sighicelli et al. 2018, Wagner \& Lambert 2018). In the presented research, this solution was not applied, due to the relatively clean water - floating waste was not observed (except for a few plastic bottles in the Rudawa River). Analogous but manual methods which do not require a large sample volume are also used; neuston nets for the surface layer, and zooplankton nets for sub-surface water (e.g.: Hidalgo-Ruz et al. 2012, Faure et al. 2012, Goldstein et al. 2013, Law et al. 2014, Baldwin et al. 2016, Eriksen et al. 2018). These methods are suitable but much better for the environment with a relatively constant flow and for waters with a low content of suspended matter. Using the appropriate volume of the containers can be burdensome for transport, but allows the collection of the same sample volume.

The method under development needs to minimize contamination. Plastic containers used for sampling are made from HDPP (High-Density Polypropylene). Samples were kept in them only for transport and were protected from exposure to solar and UV radiation. Immediately after delivery to the laboratory, the samples were filtered. Admittedly, Weinstein et al. (2016) conducted some research to prove that it is not only UV radiation that could have an influence on the speed of plastic degradation, but also living organisms and the character of the environment. They placed three different types of plastic in salt marsh for 32 weeks. The results obtained showed that after that time there had been too far advanced erosion of detected materials. In our research, the risk of getting microplastics out of the container is much lower. Both the surface and groundwater that were examined are much less aggressive than the salt marsh used in the experiment. A good argument for using containers is also the fact that in a manta trawl, a mesh with a specific diameter is used, causing the loss of smaller particles in the water (Everaert et al. 2018).

The entire volume of the samples was vacuum filtered through glass fibre filters with a pore size of $0.4 \mu \mathrm{m}$. We decided on such a methodology because it is possible to analyse the entire sample and there is less risk of losing the microplastics sought in the whole process. Density separation (Hidalgo-Ruz et al. 2012, Wagner et al. 2014, Dris et al. 2015b, Bogusz \& Oleszczuk 2016, Frère et al. 2017, Graca et al. 2017, Pagter et al. 2018) was not performed because it is only recommended for light polymers (Rezania et al. 2018).

Research on a stereoscopic microscope and the SEM/EDS examination showed the presence of particles that were considered microplastics and appear similar to those presented by other researchers (Eriksen et al. 2013, Free et al. 2014, Wagner et al. 2014, Manalu et al. 2017).

Analysis of the chemical composition by EDS showed that these compounds contain mainly carbon, which may indicate that these are microplastics particles. Unambiguous identification of what kind of plastic material it was would be possible in the DXR Raman Microscope study, but the samples were too small and the plastic particles were very dispersed. In addition, too high a temperature of the laser beam could cause the sample destruction. What is more, the research provided by Hidalgo-Ruz et al. (2012) on the marine sediment samples showed that up to $70 \%$ of particles look like microplastic are not confirmed as plastics by FT-IR spectroscopy. The use of the microscope as the sole method of microplastic analysis is inappropriate and can lead to erroneous results.

The results of the presented preliminary study showed the occurrence of the microplastic particles in fresh surface and groundwater. Studies require extensive analysis of a larger number of samples to try other techniques for sampling and microplastic separation. Research is still being carried out. 


\section{SUMMARY AND CONCLUSIONS}

In Poland, knowledge about water contamination with microplastic is still negligible, while such studies have been conducted for several years in Europe and around the world. The preliminary study shows that in Poland there are microplastics in freshwater, both in surface water and groundwater. Due to the small number of samples and the preliminary character of research, it is difficult to draw conclusions about the results obtained. In the future, we intend to collect samples with a larger volume for a more representative area during different seasons of the year. There is a need for more detailed studies focusing on the quantitative and qualitative determination of the occurrence of microplastics in waters. It is necessary to standardize methods for sampling and instrumental analysis as soon as possible, which would be accepted by most scientists to be able to compare their results. European Union actions regarding the recognition of microplastics as water pollution give hope for similar actions by the Polish government to protect water against microplastic pollution (Proposal 2018).

The study was supported by AGH UST statutory research 11.11.140.017 and 11.11.140.797.

\section{REFERENCES}

Andrady A.L., 2011. Microplastics in the marine environment. Marine Pollution Bulletin, 62, 1596-1605.

Ashton K., Holmes L. \& Turner A., 2010. Association of metals with plastic production pellets in the marine environment. Marine Pollution Bulletin, 60, 2050-2055.

Baldwin A.K., Corsi S.R. \& Mason S.A., 2016. Plastic Debris in 29 Great Lakes Tributaries: Relations to Watershed Attributes and Hydrology. Environmental Science and Technology, 50, 19, 10377-10385.

Barnes D.K.A., Walters A. \& Gonçalves L., 2010. Macroplastics at sea around Antarctica. Marine Environmental Research, 70, 250-252.

Bogusz A. \& Cejner M., 2015. Mikroplastiki w środowisku wodnym - pochodzenie, akumulacja zanieczyszczeń oraz wpływ na organizmy wodne. [in:] Olszówka M. \& Maciąg K. (red.), Nauka w służbie przyrodzie: wybrane zagadnienia, Fundacja na Rzecz Promocji Nauki i Rozwoju Tygiel Lublin, 61-73.

Bogusz A. \& Oleszczuk P., 2016. Microplastics in the environment: characteristic, identification and potential risk. Annales Universitatis Mariae Curie-Skłodowska Lublin - Polonia, 71, 2, 97-114.
Browne M.A., Crump P., Niven S.J., Teuten E., Tonkin A., Galloway T. \& Thompson R., 2011. Accumulation of microplastic on shorelines worldwide: sources and sinks. Environmental Science and Technology, 45, 9175-9179.

Butrykowska G., 2017. Występowanie mikroplastików w odchodach wydry Lutra lutra. [in:] Biopotencjał 2017 - Wydział Biologii i Nauk o Środowisku, UKSW w Warszawie [conference proceedings].

Carpenter E.J., Anderson S.J., Harvey G.R., Miklas H.P. \& Peck B.B., 1972. Polystyrene spherules in coastal waters. Science, 178, 749-750.

Carr S.A., 2017. Sources and dispersive modes of micro-fibers in the environment. Integrated Environmental Assessment and Management, 13, 3, 466-469.

Carretero O., Frias J.P.G.L., Pereiro D., Lopes C., Antunes J., Andrade J.M., Camedda A., Goruppi A., de Lucia G.A., Pedrotti M.L., Sobral P., Caetano M., Tirelli V., Nash R. \& Gago J., 2017. Microplastic sampling comparison. JPI-Oceans BASEMAN project.

Colton J.B., Knapp F.D. \& Burns B.R., 1974. Plastic Particles in Surface Waters of the Northwestern Atlantic. Science, 185, 491-497.

Davis W. \& Murphy A.G., 2015. Plastic in surface waters of the Inside Passage and beaches of the Salish Sea in Washington State. Marine Pollution Bulletin, 97, 169-177.

Dris R., Gasperi J., Rocher V., Saad M., Renault N. \& Tassin B., 2015a. Microplastic contamination in an urban area: a case study in Greater Paris. Environmental Chemistry, 12, 5, A-H.

Dris R., Imhof H., Sanchez W., Gasperi J., Galgani F., Tassin B. \& Laforsch C., 2015b. Beyond the ocean: contamination of freshwater ecosystems with (micro-) plastic particles. Environmental Chemistry, 12, 5, 539-550.

Dris R., Gasperi J., Rocher V. \& Tassin B., 2018. Synthetic and non-synthetic anthropogenic fibers in a river under the impact of Paris Megacity: Sampling methodological aspects and flux estimations. Science of the Total Environment, 618, 157-164.

Eerkes-Medrano D., Thompson R.C.\& Aldridge D.C., 2015. Microplastics in freshwater systems: A review of the emerging threats, identification of knowledge gaps and prioritisation of research needs. Water Research, 75, 63-82.

Eisma D. \& Cadeé G.C., 1991. Particulate matter processes in estuaries. [in:] Degens E.T., Kempe S. \& Richey J.E. (eds.), Biogeochemistry of Major World Rivers, Scientific Committee on Problems of the Environment, 42, John Wiley \& Sons, New York, 283-293.

Eriksen M., Mason S., Wilson S., Box C., Zellers A., Edwards W., Farley H. \& Amato S., 2013. Microplastic pollution in the surface waters of the Laurentian Great Lakes. Marine Pollution Bulletin, 77, 177.

Eriksen M., Liboiron M., Kiessling T., Charron L., Alling A., Lebreton L., Richards H., Roth B., Ory N.C., Hidalgo-Ruz V., Meerhoff E., Box C., Cummins A. \& Thiel M., 2018. Microplastic sampling with the AVANI trawl compared to two neuston trawls in the Bay of Bengal and South Pacific. Environmental Pollution, 232, 430-439.

Everaert G., Van Cauwenberghe L., De Rijcke M., Koelmans A.A., Mees J., Vandegehuchte M. \& Janssen C.R., 2018. Risk assessment of microplastics in the ocean: Modelling approach and first conclusions. Environmental Pollution, 242, B, 1930-1938, DOI: https://doi.org/10.1016/ j.envpol.2018.07.069. 
Faure F., Corbaz M., Baecher H. \& De Alencastro L.F., 2012. Pollution due to plastics and microplastics in Lake Geneva and in Mediterranean Sea. Archives des Sciences, $65,157-164$.

Fleituch T., 2016. Mikroplastiki - koń trojański ekosystemów wodnych? Chrońmy Przyrodę Ojczystą, 72, 1, 3-13.

Free C.M., Jensen O.P., Mason S.A., Eriksen M., Williamson N.J. \& Boldgiv B., 2014. High-levels of microplastic pollution in a large, remote, mountain lake. Marine Pollution Bulletin, 85, 156-163.

Frère L., Paul-Pont I., Rinnert E., Petton S., Jaffrè J., Bihannic I., Soudant P., Lambert C. \& Huvet A., 2017. Influence of environmental and anthropogenic factors on the composition, concentration and spatial distribution of microplastics: A case study of the Bay of Brest (Brittany, France). Environmental Pollution, 225, 211-222.

Gasperi J., Wright S.L., Dris R., Collard F., Mandin C., Guerrouache M., Langlois V., Kelly F.J. \& Tassin B., 2018. Microplastics in air: Are we breathing it in? Current Opinion in Environmental Science and Health, 1, 1-5.

Goldstein M.C., Titmus A.J. \& Ford M., 2013. Scales of spatial heterogeneity of plastic marine debris in the northeast Pacific ocean. PLoS One, 8, 11, e80020.

Graca B., Szewc K., Zakrzewska D., Dołęga A. \& Szczerbowska-Boruchowska M., 2017. Sources and fate of microplastics in marine and beach sediments of the Southern Baltic Sea - a preliminary study. Environmental Science and Pollution Research, 24, 8, 7650-7661.

Graham E.R. \& Thompson J.T., 2009. Deposit- and suspension-feeding sea cucumbers (Echinodermata) ingest plastic fragments. Journal of Experimental Marine Biology and Ecology, 368, 1, 22-29.

Heimowska A., 2016. Zagrożenie dla środowiska morskiego dryfującymi materiałami polimerowymi. Zeszyty $\mathrm{Na}$ ukowe Akademii Morskiej w Gdyni, 93, 141-145.

Hidalgo-Ruz V., Gutow L., Thompson R.C. \& Thiel M., 2012. Microplastics in the Marine Environment: A Review of the Methods Used for Identification and Quantification. Environmental Science and Technology, 46, 3060-3075.

Hurley R., Woodward J. \& Rothwell J.J., 2018. Microplastic contamination of river beds significantly reduced by catchment-wide flooding. Nature Geoscience, 11, 251-257.

Jastrzębska M. \& Jurczak W., 2012. Problem zaśmiecania środowiska morskiego. Logistyka, 5, 471-475.

Kłos L., 2016. Spożycie wody butelkowanej w Polsce i jej wpływ na środowisko przyrodnicze. Barometr Regional$n y, 14,1,111-117$.

Law K.L., Morét-Ferguson S.E., Goodwin D.S., Zettler E.R., Deforce E., Kukulka T. \& Proskurowski G., 2014. Distribution of surface plastic debris in the eastern Pacific Ocean from an 11-year data set. Environmental Science and Technology, 48, 4732-4738.

Lechner A., Keckeis H., Lumesberger-Loisl F., Zens B., Krusch R., Tritthart M., Glas M. \& Schludermann E., 2014. The Danube so colourful: a potpourri of plastic litter outnumbers fish larvae in Europe's second largest river. Environmental Pollution, 188, 177-181.

Li J., Liu H. \& Chen P., 2018. Microplastics in freshwater systems: A review on occurrence, environmental effects, and methods for microplastics detection. Water Research, 137, 362-374.
Lončarski M., Tubić A., Agbaba J., Jović B., Mészáros Szécsényi K. \& Dalmacija B., 2018. Characterisation of personal care products microplastics as a potential source of pollution of Danube water. [in:] Feierabend M., Novytska O., Vouk D., Šabić M. (eds.), $10^{\text {th }}$ Eastern European Young Water Professionals Conference: New Technologies in Water Sector, 7-12 May 2018, Zagreb, Croatia: Book of Abstracts, University of Zagreb, Zagreb, 63-64.

Manalu A.A., Hariyadi S. \& Wardiatno Y., 2017. Microplastics abundance in coastal sediments of Jakarta Bay, Indonesia. AACL Bioflux, 10, 5, 1164-1173.

Mato Y., Isobe T., Takada H., Kahnehiro H., Ohtake C. \& Kaminuma O., 2001. Plastic resin pellets as a transport medium for toxic chemicals in the marine environment. Environmental Science and Technology, 35, 2, 318-324.

Moore C.J., Lattin G.L. \& Zellers A.F., 2011. Quantity and type of plastic debris flowing from two urban rivers to coastal waters and beaches of Southern California. Journal of Integrated Coastal Zone Management, 11, 1, 65-73.

Morét-Ferguson S., Law K.L., Proskurowski G., Murphy E.K., Peacock E.E. \& Reddy C.M., 2010. The size, mass, and composition of plastic debris in the western North Atlantic Ocean. Marine Pollution Bulletin, 60, 10, 1873-1878.

Moatar F., Person G., Maybeck M., Coynel A., Etcheber H. \& Crouzet P., 2006. The influence of contrasting suspended particulate matter transport regimes on the bias and precision of flux estimates. Science of the Total Environment, 370, 2-3, 515-531.

Mrowiec B., 2017. Plastic pollutants in water environment. Environmental Protection and Natural Resources, 28, 4, 74, 51-55.

Mrowiec B., 2018. The role of wastewater treatment plants in surface water contamination by plastic pollutants. [in:] VI International Conference of Science and Technology INFRAEKO 2018: Modern Cities. Infrastructure and Environment: Krakow, Poland, June 7-8, 2018, E3S Web of Conferences, 45, 00054, 1-8, DOI: https://doi. org/10.1051/e3sconf/20184500054.

Pagter E., Frias J. \& Nash R., 2018. Microplastics in Galway Bay: A comparison of sampling and separation methods. Marine Pollution Bulletin, 135, 932-940.

Plastics, 2017. Plastics - the Facts 2017: An analysis of European plastics production, demand and waste data. Plastics Europe, Association of Plastic Manufacturers, Brussels.

Proposal, 2018. Proposal for a Directive of the European Parliament and of the Council on the quality of water intended for human consumption (recast). COM/2017/0753 final - 2017/0332 (COD).

Rezania S., Park J., Md Din M.F., Mat Taib S., Talaiekhozani A., Kumar Yadav K. \& Kamyab H., 2018. Microplastics pollution in different aquatic environments and biota: A review of recent studies. Marine Pollution Bulletin, 133, 191-208.

Rillig M.C., Ziersch L. \& Hempel S., 2017. Microplastic transport in soil by earthworms. Scientific Reports, 7, 1, 1-6.

Rios L.M., Moore C. \& Jones P.R., 2007. Persistent organic pollutants carried by synthetic polymers in the ocean environment. Marine Pollution Bulletin, 54, 8, 1230-1237. 
Song Y.K., Hong S.H., Jang M., Kang J.H., Kwon O.Y., Han G.M. \& Shim W.J., 2014. Large accumulation of micro-sized synthetic polymer particles in the sea surface microlayer. Environmental Science and Technology, 48, 16, 9014-9021.

Sighicelli M., Pietrelli L., Lecce F., Iannilli V., Falconieri M., Coscia L., Di Vito S., Nuglio S. \& Zampetti G., 2018. Microplastic pollution in the surface waters of Italian Subalpine Lakes. Environmental Pollution, 236, 645-651.

Simpson S.L., Batley G.E., Chariton A.A., Stauber J.L., King C.K., Chapman J.C., Hyne R.V., Gale S.A., Roach A.C. \& Maher W.A., 2005. Handbook for Sediment Quality Assessment. CSIRO, Bangor, NSW.

Sprawozdanie, 2017. Sprawozdanie $z$ rejsu badawczego $R / V$ Oceania: AREX 2017: 14.06.2017-29.08.2017. [on-line:] https://www.iopan.pl/oceania/Arex2017_Raport.pdf [access: 15.07.2018].

Thompson R.C., Olsen Y., Mitchell R.P., Davis A., Rowland S.J., John A.W.G., McGonigle D. \& Russell A.E., 2004. Lost at sea: where is all the plastic? Science, 304, 5672, 838.
Wagner M., Scherer C., Alvarez-Muñoz D., Brennholt N., Bourrain X., Buchinger S., Fries E., Grosbois C., Klasmeier J., Marti T., Rodriguez-Mozaz S., Urbatztka R., Vethaak A.D., Winther-Nielsen M. \& Reifferscheid G., 2014. Microplastics in freshwater ecosystems: what we know and what we need to know. Environmental Sciences Europe, 26, 12, DOI: https://doi.org/10.1186/s12302014-0012-7.

Wagner M. \& Lambert S., 2018. Freshwater Microplastics: Emerging Environmental Contaminants? The Handbook of Environmental Chemistry, 58, Springer Open.

Weinstein J.E., Crocker B.K. \& Gray A.D., 2016. From macroplastic to microplastic: degradation of high-density polyethylene, polypropylene, and polystyrene in a salt marsh habitat. Environmental Toxicology and Chemistry, 35, 7, 1632-1640.

Westphalen H. \& Abdelrasoul A., 2018. Challenges and Treatment of Microplastics in Water. [in:] Glavan M. (ed.), Water Challenges of an Urbanizing World, IntechOpen, 71-83. 